\title{
IfIISGUC.ORG
}

"İȘ, GÜC̣" ENDÜSTRi ilLișKiLERI VE INSAN KAYNAKLARI DERGISi

"IS, GUC" INDUSTRIAL RELATIONS AND HUMAN RESOURCES JOURNAL

\section{Kurumdan Ayrilma Niyetini Etkileyen Unsurlar: İşe Bağlılık ve Kurumla Özdeşleşme}

Elements That Effect Intentions To Leave: Job Involvement And Organizational

\section{Yrd.Doç.Dr.Füsun BULUTLAR}

Yeditepe Üniversitesi

Yrd.Doç.Dr.Ela Ünler ÖZ

Bahçeşehir Üniversitesi

Nisan/April 2010, Cilt/Vol: 12, Say1/Num: 2, Page: 75-88

ISSN: 1303-2860, DOI: 10.4026/1303-2860.2010.144.x

Makalenin on-line kopyasına erişmek için:

http://www.isguc.org/?p=article\&id=408\&vol=12\&num=1\&year=2010

To reach the on-line copy of article:

http://www.isguc.org/?p=article\&id=408\&vol=12\&num=1\&year=2010

Makale İçin İletişim/Correspondence to: 
(C) 2000- 2010

"İşGüç" Endüstri İlişkileri ve İnsan Kaynakları Dergisi

"İşGüç" Industrial Relations and Human Resources Journal

Nisan/April 2010, Cilt/Vol: 12, Say1/Num: 2

ISSN: 1303-2860, DOI: 10.4026/1303-2860.2010.144.x

Editör/Editor-in-Chief

Aşkın Keser (Kocaeli University)

Editör Yardımcıları/Co-Editors

K.Ahmet Sevimli (Uludağ University)

Gözde Yılmaz (Kocaeli University)

Uygulama/Design

Yusuf Budak (Kocaeli Universtiy)

\author{
Yayın Kurulu / Publishing Committee \\ Dr.Zerrin Firat (Uludăg University) \\ Doç.Dr.Aşkın Keser (Kocaeli University) \\ Prof.Dr.Ahmet Selamoğlu (Kocaeli University) \\ Yrd.Doç.Dr.Ahmet Sevimli (Uludağ University) \\ Yrd.Doç.Dr.Abdulkadir Şenkal (Kocaeli University) \\ Yrd.Doç.Dr.Gözde Yilmaz (Kocaeli University) \\ Dr.Memet Zencirkıran (Uludağ University)
}

Uluslararası Danışma Kurulu / International Advisory Board

Prof.Dr.Ronald Burke (York University-Kanada)

Assoc.Prof.Dr.Glenn Dawes (James Cook University-Avustralya)

Prof.Dr.Jan Dul (Erasmus University-Hollanda)

Prof.Dr.Alev Efendioğlu (University of San Francisco-ABD)

Prof.Dr.Adrian Furnham (University College London-İngiltere)

Prof.Dr.Alan Geare (University of Otago- Yeni Zellanda)

Prof.Dr. Ricky Griffin (TAMU-Texas AEM University-ABD)

Assoc. Prof. Dr. Diana Lipinskiene (Kaunos University-Litvanya)

Prof.Dr.George Manning (Northern Kentucky University-ABD)

Prof. Dr. William (L.) Murray (University of San Francisco-ABD)

Prof.Dr.Mustafa Özbilgin (University of East Anglia-UK)

Assoc. Prof. Owen Stanley (James Cook University-Avustralya)

Prof.Dr.Işık Urla Zeytinoğlu (McMaster University-Kanada)

Danışma Kurulu / National Advisory Board

Prof.Dr.Yusuf Alper (Uludağ University)

Prof.Dr.Veysel Bozkurt (Uludağ University)

Prof.Dr.Toker Dereli (Işık University)

Prof.Dr.Nihat Erdoğmuş (Kocaeli University)

Prof.Dr.Ahmet Makal (Ankara University)

Prof.Dr.Ahmet Selamoğlu (Kocaeli University)

Prof.Dr.Nadir Suğur (Anadolu University)

Prof.Dr.Nursel Telman (Maltepe University)

Prof.Dr.Cavide Uyargil (İstanbul University)

Prof.Dr.Engin Yildırım (Sakarya University)

Doç.Dr.Arzu Wasti (Sabancı University)

Dergide yayınlanan yazılardaki görüşler ve bu konudaki sorumluluk yazarlarma aittir.

Yayınlanan eserlerde yer alan tüm içerik kaynak gösterilmeden kullanılamaz.

All the opinions written in articles are under responsibilities of the outhors.

None of the contents published can't be used without being cited. 


\title{
Kurumdan Ayrilma Niyetini Etkileyen Unsurlar: İşe Bağlılık ve Kurumla Özdeşleşme
}

\author{
Elements That Effect Intentions To Leave: \\ Job Involvement And Organizational
}

\author{
Yrd.Doç.Dr.Füsun BULUTLAR \\ Yeditepe Üniversitesi \\ Yrd.Doç.Dr.Ela Ünler ÖZ \\ Bahçeşehir Üniversitesi
}

\begin{abstract}
Özet:
Çalışmamızın amacı, işe bağlllık ve kurumla özdeşleşmenin kurumdan ayrllma niyeti üzerinde ne oranda farklı etkileri olduğunu araştırmaktır. Bunun yanında, kurumla özdeșleșmenin işe bağhllı ve kurumdan ayrlma niyeti arasindaki iliş̧kide şartlı değgişken olarak rol alıp almadı̆̆ını anlamaya çalışmaktır. Yapılan anket çalışmasına toplam 271 hizmet çalı̧̧anı katılmıştır. Araştırmanın sonucunda, kurumla özdeşleşmenin kurumdan ayrılma niyeti üzerindeki etkisinin işe bağllihğa göre daha yüksek olduğu bulunurken, özdeşleşmenin şartlı değigşken olarak rol almadığı anlaşılmıştır.
\end{abstract}

Anahtar Sözcükler: İşe Bağlllık, kurumla özdeşleşme, kurumdan ayrllma niyeti, şartlı değişken, yönetsel uygulamalar

\begin{abstract}
:
IThe aim of the study is to explore the difference between the effects job involvement and organizational identification on intention to leave and to find out if organizational identification has any moderating effect on the relation between job involvement and intention to leave. 271 service employees were included to the survey administered for this purpose. According to our results, organizational identification has greater negative effect on intention to leave than job involvement. Additionally, organizational identification does not have any moderating role between job involvement and intention to leave.
\end{abstract}

Keywords: Job involvement, organizational identification, intention to leave, moderating variable, managerial implications. 


\section{GiRiş}

Küreselleşme ve teknolojideki gelişmeler sonunda günümüzde daha da yoğunlaşmış olan aşırı rekabetçi ortam, kurumların rakiplerine oranla daha üstün ve farklı olmak için gösterdikleri çabaları arttırmıştır. Kurumlar söz konusu farklılık ve üstünlüğü ancak sahip oldukları entellektüel sermaye sayesinde arttırabileceklerinin bilincine varmışlardır. Çalışanların kendilerine özgü kişilikleri, güdülenmeleri, fikirleri ve değerleri göz önünde bululundurulduğunda kurumların kopyalanması en zor unsurunun beşeri sermayesi olduğu görülmektedir. Diğer bir deyişle, çalışanların kişilikleri, güdülenmeleri, fikirlerinin yanı sıra örgütün kültürel değerleri ve bireylerin örtük bilgileri kopyalanamaz. Yetenek ve yetkinlikleri yitirmenin yanı sıra, çalışanların işten ayrılmaları, yeni işe alım ve oryantasyon maliyetlerini arttırması açısından da kurumlara ek yük getirir (Loi, Hang-yue ve Foley, 2006:101). Kurumdan ayrilma niyeti olan kişilerin bilgilerini kendilerine saklamaları halinde sosyalleşme yolu ile aktarılan örtük bilgi kurum içerisinde yaygınlaşamayacak ve söz konusu kisiler niyetlerini gerçekleștirdiklerinde bilgilerini beraberlerinde götüreceklerinden kurum bu bilgileri kaybetmiş olacaktır. Dolayısı ile, kurumdan ayrılmanın başta gelen öncellerinden olan ayrılma niyeti (Griffeth vd., 2000:482; Scott vd., 1999:401) önemli bir unsur olarak ortaya çıkmaktadır. Çoğu yazar, gerçekten işten ayrılma eylemi yerine işten ayrılma niyetininin araştırılmasının çok daha avantajlı olacağını savunmaktadır (Shore, Newton, ve Thornton, 1990:59). Baz1 yazarlar ise iş ile ilgili pek çok değişken ile işten ayrılma niyeti arasındaki ilişkinin gerçekten işten ayrılma ile adı geçen değişkenler arasındaki ilişkiden daha kuvvetli olduğunu gözlemlemişlerdir (Somers, 1995:51; Kirschenbaum ve Weisberg, 1991:360).

Kurumdan ayrılma niyetini etkileyen başlıca değişkenlerin arasında kuruma bağlılık (Somers, 1995:51) ve özdeşleşme (Tüzün, 2007:129; Cole ve Bruch, 2006:591; Harris ve
Cameron, 2005:162; Kitapçı, Çakar ve Sezen, 2005:35; Scott vd., 1999:401; Mael ve Ashforth, 1995:314) olduğu gözlemlenmiştir. Ayrıca Blau ve Boal (1987:292) işe bağlılığın iş devir oranı üzerinde etkili olduğunu belirtmişlerdir. Daha önce yapılmış araştırmalarda kurumdan ayrılma niyetinin sonuçları üzerinde durulmuş olsa da, öncelleri ihmal edilmiştir.

Bu bağlamda, çalışmanın amacı işe bağlılık (işi benimseme) ve kurumla özdeşleşmenin kurumdan ayrılma niyetini nasıl ve ne oranda etkilediğini bulmaya çalışmaktır.

\section{2..KURAMSAL ÇERÇEVE}

\subsection{Kurumdan ayrulma niyeti}

Tüzün (2007:129) kurumdan ayrilma niyetinin bir kimsenin işi bırakma eğilimi olarak tanımlanabileceğini ifade etmiştir. Price (1977: 4) ise daha karmaşık bir tanım yaparak ayrilma niyetinin üyesi olunan sosyal sistemin sınırlarına doğru hareket etme oranı olduğunu belirtmiştir. Kısaca, söz konusu kavram, yakın zamanda bilinçli ve istekli şekilde kurumdan ayrılma eğilimi göstermek olarak tanımlanabilir (Tett ve Meyer 1993:262). Ayrılma niyeti iş devir oranının en önemli önceli olarak görülmektedir (Shore ve Martin, 1989:626). İş devir oranı yüksek olan kurumlarda gerek kurum, gerekse de çalışanlar açısından birçok olumsuzluklar yaşanmaktadır. Yetenekli iş gücünü kaybetme olasılığının sürdürülebilir rekabet avantajını olumsuz yönde etkilemesi ve yeni işe alınacak olan elemanlara verilecek eğitimin yanı sıra işe alım maliyetleri, kurumlara getireceği olumsuzlular arasinda yer almaktadır (Bibby, 2008:64). Bunun yanında, o iş yerinde çalışmaya devam eden kişilerin iş arkadaşlarını kaybetmelerinden dolayı yaşayacakları üzüntü ve yeni gelenler ile yaşanacak ilişkinin belirsizliğinden doğan endişe kişiler için ortaya çıkan sorunlar olarak sayılmaktadır (Scott vd., 1999:401). İsyerinden ayrılma niyetinin sözü edilen olumsuz etkileri göz önünde bulundurulduğunda, kurumdan ayrılma niyetinin anlaşı- 
ması, öncellerinin ortaya çıkartılarak ya da adı geçen kavramı olumsuz yönde etkileyecek unsurların ortaya çıkartılması, iş devir oranının düşmesi açısından gereklilik taşımaktadır.

\subsection{Kurum ile özdeşleşme}

Özdeşleşme en basit şekilde bireyin kendisini belli bir gruba bağlı olmak yönündeki alg1sı olarak tanımlanabilir (Mael ve Ashforth, 1995:311). Kurumla özdeşleşme kavraminin temelinde psikolojide yer alan sosyal kimlik teorisi vardır. Bu teoriye göre, bireyler çevrelerinde bulunan grupları sınıflandırırken kendilik özelliklerinden (selfconcept) en belirgin olanlarını göz önünde bulundururlar. Kişilerin bu şekilde sınıflandırmalar yapmaları, çevrelerini düzenlemelerine, ve dolayısı ile kendilerini ve başkalarını bu gruplara yerleştirmelerine yardımc1 olur (Mael ve Ashforth, 1992:105). Bireyler ait olduklarını düşündükleri grubun bir üyesi olarak ortak bir kadere sahip olduklarını, başarı ve başarısızlıkları paylaştıklarını düşünürler. Herhangi bir grup ile özdeşleşmeye başladıklarında bireyler gruba ait tipik davranışları kendi davranışlarıymış gibi düşünürler ve kimiliklerini, amaç ve hedeflerini, tutumlarını, yapacaklarını ait oldukları grup aracılığı ile tanımlarlar (Mael ve Ashforth, 1995:310). Kurumla özdeşleşme ise, sosyal özdeşleşmenin bir çeşididir. Kurumla özdeşleşme söz konusu olduğunda kişi yerleştiği grup olarak kurumunu seçer. Dolayısı ile kurumla özdeşleşme, bireylerin kendilerini kurumlarınin bir unsuru olarak tanımlamaları ya da kişinin kendisini kurum ile fikir birliği içinde ve güvende olarak algılaması veya hissetmesi olarak tanımlanabilir (Mael ve Ashforth, 1995:312). Cole ve Bruch (2006:588) kurumu ile özdeşleşen kişilerde kurum kimliği ile kişinin kimliğinin psikolojik olarak ortak hale geldiğini belirtmişlerdir. Kurum özellikleri ve değerleri bireylerin "Ben kimim?" sorusunu cevaplamalarında yardımcı olur. Dolayısı ile bir çalışan kurumu ile ne kadar özdeşleşirse, kurumun amaç ve hedeflerini o derecede benimseyecek ve bu doğrultuda davranışlar sergileyecektir, çünkü kendisini kurumu ile ortak payda içerisinde hissetmektedir.

Kurum ile özdeşleşme ve kuruma bağlllık çok yakın kavramlar olduğu için çoğunlukla birbirlerine karıştırılabilmektedirler, bu nedenle aralarındaki farklılığın vurgulanması gerektiği düşünülmektedir. Allen ve Meyer (1990:3) kuruma bağlılığ çalışanın kendi isteği ile kurumdan ayrılma olasılığını azaltan ve kurum ile arasında oluşan psikolojik bir bağ olarak tanımlamışlardır. Her ne kadar psikolojik süreçleri içerse de sonuç olarak davranıș odaklı bir tutumdur (Ketchand ve Strawser, 2001:231). Özdeşleşme ise bilişsel ve psikolojik bir süreçtir. Kuruma bağlı bir çalışan kurumdan ayrıldı ̆̆ında kendisini bir parçasını kaybetmiş gibi hissetmez, ancak, kurum ile özdeşleşmiş kişiler kendi kimliklerini kurum aracılığ 1 ile tanımladıkları için kurumdan ayrıldıklarında bir parçalarını yitirmiş gibi hissederler. Aynı zamanda, kurumlarına bağlı çalışanların amaç ve hedefleri kurumun amaç ve hedefleri ile iç içe geçmemiştir, daha çok kendileri ile ilgili amaç ve hedefleri vardır ve bu nedenden ötürü kendilerini kurumları ile kader birliği içinde hissetmezler. Diğer yandan özdeşleşmiş çalışanlar için kurumun amaç ve hedefleri kendi amaç ve hedefleri haline gelmiş olduğu için kurum ile kader birliği ettiklerini düşünürler (Cole ve Bruch, 2006:585; Mael ve Ashforth, 1995:310). Örneğin kurumuna bağlı bir çalışan daha iyi bir teklif almadığ1 için kurumda kalmayı yeğlerken, kurum ile özdeş bir çalışan orayı kendi özel iş yeri gibi hissettiği ve gerçekten orada kalmak istediği için kalmayı tercih edebilir (Ashforth ve Mael, 1989:22). Bunun yanında, Mael ve Ashforth (1995:312), kurumuna bağlı bir kişinin çalıştı̆̆ kurumun en önemli rakiplerinden birinden aldığ 1 cazip teklifi kendisi için faydalı olduğunu düşündüğü takdirde geri çevirmeyerek iş yerini değiştirebileceğini belirtmişler ve bağlllı̆̆ın kişikurum arasındaki sosyal-takas ile alakalı olduğunu vurgulamışlardır. Kurumla özdeşleşme ise kuruma-özel bir kavramdır ve sosyal-takasla ilişkili değildir. Ayrıca, iş ye- 
rinin değer ve hedeflerini benimseyen kurumu ile özdeşleşmiş çalışanlar için yazılı kural ve prosedürlere gerek yoktur; onlar doğal olarak bu doğrultuda davranırlar. Örgüte bağlı çalışanlar ise kurallar ve yöneticiler tarafindan yönlendirilme sonucunda istenen davranışları gerçekleştirirler (Gautam, Van Dick ve Wagner, 2004:305).

Cameron (2004:241) sosyal özdeşleşmenin üç alt boyutunu merkeziyet (centrality), grup-içi duygu (in-group affect) ve grup-içi bağlar (in-group ties) olarak tanımlamıştır. Diğer taraftan, kuruma bağlılık da içten (duygusal), minnet ve çıkar olmak üzere üç alt boyuttan oluşmuştur (Allen ve Meyer, 1990:3). Harris ve Cameron (2005:160) ise bağlılık ve özdeşleşme arasındaki benzerlik ve farklılıkları söz konusu boyutlar yardımı ile açıklamışlardır. Sosyal özdeşleşmeyi oluşturan boyutlardan merkeziyet, bireyin grubu hayatının bir parçası olarak görmesi ve kendisini tamamen yansıttığını düşünmesidir. Bireyin ait olduğu grubu sübjektif olarak değerlendirmesi ve bu grupta ait olmaktan ötürü olumlu duygular hissetmesi grup-içi duyguyu, grubun diğer üyeleri ile sıkı bağlar kurması ise grup-içi bağları açıklamaktadır. Bu nedenle merkeziyet özdeşleşmenin bilişsel kısmını, grup-içi duygu ve grup-içi bağlar ise duygu kısmını içerir (Harris ve Cameron, 2005:160). Diğer taraftan, içten bağlılık (affective commitment), çalışanın kendisini iş yerine duygusal olarak bağlı hissetmesi, minnet bağ l1lığ 1 (normative commitment) kuruma karşı sorumluluk veya borçlu hissetmesi, çıkar bağlılığ1 (contunuance commitment) ise başka alternatifi olmaması ve işten ayrılmanın getireceği olumsuzluklarin hesaplanması durumudur (Allen ve Meyer 1990:4). Yukarıdaki tanımlardan da anlaşılacağı gibi sadece içten bağlılık özdeşleşmenin alt boyutları ile ilişkilendirilebilir (Harris ve Cameron, 2005:161). Minnet ve çıkar bağlılıkları, sırasıyla çalışanın kendisini iş yerine borçlu hissetmesi ve çalışanın iş yerinden ayrılmayı bir maliyet olarak görmesi ile ilgili oldukları için olumsuz duyguları da içermektedirler. Bu yüzden minnet ve çıkar bağlılıkları ile öz- deşleşme arasında bağlantı kurulamamıştır. Diğer taraftan, içten bağl1lık boyutunda çal1şanlar duygusal bir bağlılık hissettiği için, özdeşleşmenin grup-içi duygu ve grup-içi bağlar boyutu ile ilişkilendirilebilmektedir. Yazarlar, bu tür bir analizin bağlılık ve özdeşleşme arasındaki benzerlik ve farklılıkların anlaşılabilmesi için faydalı olmasının yanı sıra, her iki değişkenin sonuçlarını yordama da katkı sağlayabileceğini iddia etmektedirler (Harris ve Cameron, 2005:162).

\subsection{Kurumdan Ayrilma Niyeti ve Kurumla Özdeşleme arasındaki İlişki}

Kurum ile özdeşleşmeyi ölçmek için Cheney (1983:352) tarafından geliştirilen ilk ölçüm aracında üç alt boyut göz önünde bulundurulmuştur. Bunlar; 1) bağlılık, aitlik hissi ve o kurumun üyesi olmanın verdiği gurur, 2) kuruma sadakat ve kurumun hedeflerini benimseme, 3) çalışanlar ve kurum değer ve hedeflerinin benzerliği (Gautam, Van Dick ve Wagner, 2004:302). Bu boyutlar göz önünde bulundurulduğunda, kurumun üyesi olmaktan gurur duyan, hedeflerini benimseyen, ve kuruma sadık olan çalışanlarin kurumdan ayrılma niyetlerinin olmasının pek olası olmadığı görülmektedir.

Ayrıca, daha önce yapılmış olan pek çok araştırmada kurumla özdeşleşmenin kurumdan ayrılma niyetini azalttığ1 gözlemlenmiștir (Tüzün, 2007:129; Cole ve Bruch, 2006:591; Haris ve Cameron, 2005:166; Kitapç1, Çakar ve Sezen, 2005:37;Scott vd., 1999:419; Mael ve Ashforth, 1995:314). Bulundukları kurumun bir parçası olmaktan gurur duyan çalışanlar, o kurumun bir parçası olarak kalmak isteyecekler, dolayısı ile kurumdan ayrilma gibi bir niyetleri olmayacaktır (Tüzün 2007:129). Ayrıca, özdeşleşme arttıkça çalışanlar yabancılık hissetmeyerek kendilerini kurum ile kader ortağı olarak görecek ve başka bir kurumda çalışma ihtiyacı ortaya çıkmayacaktır (Van Knipperberg ve Van Schie, 2000:137). Wegge ve arkadaşlarının (2006:78) özdeşleşme ve iş tutumları hakkında yaptıkları bir araştırmada, kurumla özdeşleşmenin yarattığ1 ortak kimlik olgu- 
sunun bireylerde sosyal destek ve başetme yolu olarak algilanarak kurumdan ayrılmak

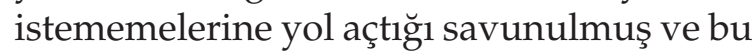
durum istatistiksel olarak kanıtlanmıştır.

Harris ve Cameron (2005:162) her çalışanın kurum ile özdeşleşme sebebinin farklı olması nedeniyle ayrilma niyetlerinin de o oranda farklı olacağını belirtmişlerdir. Örneğin bir çalışan kurumun olumlu duygular yaratması sonucunda (grup-içi duygusal özdeşleşmesi) oradan ayrılmak istemezken, başka bir çalışanın kurumdan ayrılma niyetinin azalması kurumun diğer üyeleri ile kurduğu sıkı ilişkiyi (grup-içi bağ özdeşleşmesi) bırakmak istememesine, ya da kişinin kurumu hayatının bir parçası ve kendisini ifade etme yolu olarak görmesine bağlı olabilir. Sonuç olarak;

H1: Kurumla özdeşleşme arttıkça kurumdan ayrılma niyeti azalacaktır.

\subsection{Iş̧e Băglılık}

Kurumla özdeşleşme bireyin kurum ile özdeşleşmesini ifade derken, işe bağlılık da bireyin psikolojik olarak işi ile özdeşleşmesi olarak tanımlanabilir (Blau, 1985:578). İşe bağlliık, çalışanların kendilerini işlerine içten bağlı hissetmeleri ve işlerinden tatmin olduklarını anlamina gelmektedir (Lorence ve Mortimer, 1985; aktaran Kruml, 1999:10). Hafer ve Martin (2006:3) ise işe bağl1lığ1; “bireylerin işlerini işin içeriği ve işlerinin özel hayatları ile ne oranda içiçe olduğuna göre değerlendirmeleri" olarak tanımlamıştır. İşe bağlılık, çalışanların performans düzeylerini önemsemesini ve başarılı olmak için uğraş vermelerini sağlar, çünkü işe bağlı çalışanlar başarı gösterdikçe öz yeterlilik inançlarının da arttığını düşünürler (Robbins, 2007:80; Blau and Boal, 1987:290). İşe bağlı çalışanlar yaptıkları işten zevk alırlar çünkü işlerini severek yaparak iş süreçlerine kendilerine has özellikler katarlar. Bunun yanında işlerine bağlı olmayan çalışanlar kendilerini amaçsız hissederek, çalıştıkları kuruma yabancılaşırlar (Hafer ve Martin, 2006:3).

\subsection{Isşe Bağlılık ve Kurumdan Ayrılma Ni- yeti Arasındaki İlişki}

Araştırmalar, işe bağlı çalışanların iş tatminlerinin yüksek, kurumdan ayrılma niyetlerinin ise düşük düzeyde olduğunu göstermektedir (Godwin, Guimaraes ve Igbaria, 1997:917; Blau and Boal, 1987:294). İşe bağlılığı yüksek çalışanlar işleriyle fazlasıyla meşgul oldukları için motivasyonları yükselmekte, böylelikle kurumdan ayrılma niyetleri de azalmaktadır (Diefendorff, Brown, Kamin ve Lord, 2002:94). İşe bağlılık, çalışanın işini istekli gerçekleştirmesini ve böylelikle kurum amaçları ile paralel çalışmasını sağlamaktadır (Diefendorff, Brown, Kamin ve Lord, 2002:92). Bu yüzden, birey kurum amaçlarına ulaştıkça performansı artacak ve performansının yüksek olduğu kurumdan ayrılmak istemeyecektir. Buna göre,

H2: İşe bağlılık arttıkça kurumdan ayrılma niyeti azalacaktır.

\section{6 İşe Bağhlık, Kurumla Özdeşleşme ve Ku- rumdan Ayrulma Niyeti}

İşine bağlı, örgütü ile özdeş çalışanların kurumdan ayrılma niyetleri, yukarıda ifade edilen etkilerden daha güçlü olacaktır. İşine bağlı bir çalışan içsel gelişme ihtiyacını tatmin ederken (Kanungo, 1982:342), kurumu ile özdeş çalışan sosyal yani dişsal gelişme ihtiyacinı tatmin edebilmektedir (Blau, 1985:578). Bu yüzden bu tür iki ihtiyacın karşılanması ile bu iki değişkenin (işe bağlılık ve kurumla özdeşleşme) etkileşiminin kurumdan ayrilma niyetine etkisi, herbirinin söz konusu değişkene etkisinden daha yüksek olacaktır. Bu yüzden;

H3: Kurumla özdeşleşme arttıkça, işe bağl1lık ile kurumdan ayrılma niyeti arasındaki ters ilişki güçlenecektir..

\section{YÖNTEM}

\subsection{Denekler}

Anketler, bankacılık sektöründe çalışan 400 kişiye dağıtılmış, 278 tanesi geri dönmüş, dolayısı ile geri dönüş oranı $\% 68.5$ olmuştur. 
Anketlerden yedi tanesi kullanilamaz olduğu için çıkartılmış ve analizler 271 anket üzerinden yapılmıştır. Ankete katılanların $\% 52$ 'si kadın, \%45'i erkek iken yaş ortalamaları 29,7 ve şu anki iş yerlerindeki ortalama çalışma süreleri 3.64 yıldır.

\section{2 Ölçme araçları}

Tüm ölçekler Türkçe'ye çevrilmiştir. İfadelerin İngilizce ve Türkçe karşılıkları 10-15 kişiye verilerek bu ifadelerin ne oranda aynı anlamlara geldiği sorulmuş ve verilen cevaplara göre düzenlenmiştir. Tüm ifadelerin cevap seçenekleri, "Hemen hemen hiçbir zaman'dan (1)", "Hemen hemen her zaman'a (6)" kadar uzanan 6'll ölçekten oluşmaktadır.

Kurumdan ayrilma niyeti, Grandey (1999:30)'in doktora tezi için kullandığ 3 ifade ile ölçülmüștür. Ölçekte, "Șimdiki işimden ayrılmayı düşünüyorum" ve "Sürekli olarak daha iyi bir iş arıyorum" gibi ifadeler bulunmaktadır.

Kurumla özdeşleşme, Mael ve Asforth'un (1992:110) hazırladığ1 6 ifade ile ölçülmüștür. Ölçek, "Ne zaman biri kurumumu eleştirse, bunu kendime yapılmış bir hakaret olarak hissederim" ve "Ne zaman biri kurumumu övücü sözler söylese, bunu kendime yapılmış bir iltifatmış gibi hissederim" gibi ifadelerden oluşmaktadır.

İşe bağlılık için, Lodahl ve Kejner (1965:27)'in geliştirmiş oldukları 7 ifadelik ölçek kullanılmıştır. Ölçekte, "Hayatımın en önemli şeyleri işimle ilgili olanlardır" ve "Başka şeyler ile meşgulken bile aklımda işim vardır" gibi ifadeler yer almaktadır.

\subsection{Uygulama}

Anketler kişilere bizzat ulaştırılarak ve internet yolu ile doldurtulmuştur. Elden verilen tüm anketler kapalı zarf içinde teslim alınıştır. Araştırmacılar anketlerdeki bilgilerin gizli kalacağına ve kesinlikle isim yazılmaması gerektiğine dikkat çekmiştir. Anketler bir ay içerisinde toplanmıştır. Anketlerin geri dönüş oran1 \% 68,5'dur.

\subsection{Kullanilan istatistiksel analizler}

Kurumla özdeşleşme, işe bağlıllı ve kurumdan ayrılma niyeti ölçeklerinin her birine güvenilirlik testi yapılmıştır. Kurumdan ayrılma niyeti ölçeğinin soru sayısı faktör analizi uygulaması için yeterli olmadığından, sadece işe bağlllık ve kurumla özdeşleşme ölçeklerine faktör analizleri uygulanmıştır. Bağımsız (işe bağlılık ve kurumla özdeşleşme) değişkenlerin bağımlı (kurumdan ayrılma niyeti) değişken üzerindeki etkisi çoklu regresyon analizleri ile incelenmiştir. Aynı zamanda kurumla özdeşleşmenin işe bağl1lik ve kurumdan ayrilma niyeti arasında şartlı değişken olarak rol alıp almadığı hiyerarşik regresyon analizi ile test edilmiştir.

\section{BULGULAR}

\subsection{Faktör analizi sonuçları}

Kurumla özdeşleşme ve işe bağlılık için yapılan faktör analizi sonuçlarından bu ölçeklerin herhangi bir faktör oluşturamadığ 1 anlaşılmıştır. Buna göre, ölçeklerle ilgili betimsel istatistikler ve ölçekler arası korelasyonlar hesaplanmıştır. Tablo 1'de sonuçlar gösterilmiştir.

Tablo 1

Ölçeklerarası Korelasyonlar

\begin{tabular}{|l|c|c|c|c|}
\hline Ölçek & $\mathbf{N}$ & $\mathbf{1}$ & $\mathbf{2}$ & $\mathbf{3}$ \\
\hline 1. Kurumdan Ayrılma Niyeti & 269 & - & & \\
2. Kurumla Özdeşleşme & 258 & $-.319^{* * *}$ & - & \\
3. İşe Bağlılık & 252 & $-.144^{* * *}$ & $.616^{* * *}$ & - \\
\hline
\end{tabular}

${ }^{*} p<0,05^{* *} p<0,01{ }^{* * *} p<0,001$ 


\subsection{Kurumla Özdeşleşme, İşe bağlılık ve Ku- rumdan Ayrılma Niyeti İlişkisi}

Kurumla özdeşleşme ve işe bağlılığın kurumdan ayrılma niyeti üzerindeki etkisi çoklu regresyon analizi ile test edilmiştir. Analiz sonucunda, kurumla özdeşleşmenin ( =-.319) ayrılma niyetini işe bağlılığa ( =.144) göre daha yüksek oranda etkilediği bulunmuştur. Bu sonuçlara göre $\mathrm{H} 1$ ve $\mathrm{H} 2$ desteklenmiştir

Çoklu regresyon sonuçları Tablo 2'de gösterilmiştir.

\subsection{Kurumla Özdeşleşmenin Şarth Değişken Olarak Rolü}

Kurumdan ayrılma niyeti ve işe bağlılık arasındaki ilişkide etkisi olduğunu düşündüğü- müz kurumla özdeşleşme hiyerarşik regresyon analizi ile test edilmiştir. Şartlı değişkenin rolü, bağımsız değişken ile şartlı değişkenin etkileşimi alınarak bakılmıştır. Değişkenlerin etkileşimini bulurken öncelikle her teste verilen cevap puanlarının normal dağılım gösterip göstermediğine bakılmıştır. Normal dağılım gösterenlerin ham puanları o test için hesaplanan ortalamadan çıkartılarak, dağılmayanlar için ise ortalamaları çıkartılıp standart sapmasına bölünerek standart puanları hesaplanmıştır. İşe bağlilığın kurumla özdeşleşme ile etkileşimini bulabilmek için işe bağlılığın standart puanı ile kurumla özdeşleşmenin standart puanı çarpılmıştır.

Analizin birinci basamağına işe bağlılık ve kurumla özdeşleşme ayrı ayrı analize dahil edilirken, ikinci basamakta işe bağlılığın ku-

Tablo 2

İşe Bağlılık, Kurumla Özdeşleşme ve Kurumdan Ayrılma Niyeti İlişkisi

\begin{tabular}{|c|c|c|c|r|c|c|c|}
\hline R2 & Düzeltilmiş R2 & $\mathbf{F}$ & $\mathbf{P}$ & & Beta & T & p \\
\hline .180 & .172 & 23.852 & .007 & İşe Bağllık & -.144 & -1.847 & .050 \\
\cline { 5 - 8 } & & & & Kurumla Özdeşleşme & -.319 & -4.082 & .000 \\
\hline
\end{tabular}

Bă̆ımsız değişkenler: İşe Bă̆lllık, Kurumla Özdeşleşme

Bağımlı değişken: Kurumdan Ayrılma Niyeti

\section{Tablo 3}

Kurumla özdeşleşmenin İşe Bağlılık ve Kurumdan Ayrılma Niyeti Arasında Şartlı Değişken Olarak Rolü

\begin{tabular}{|l|c|c|c|c|c|}
\hline Değişkenler & B & Beta & Düzeltilmiş R2 & R2 Fark1 & F \\
\hline $\begin{array}{l}\text { 1.Basamak } \\
\text { Kurumla Özdeşleşme }\end{array}$ & $-.314^{* * *}$ & $-.319^{* * *}$ & .163 & $.167^{* * *}$ & $43.808^{* * * *}$ \\
\hline İşe Bağlllık & $-.183^{*}$ & $-.144^{*}$ & .172 & $.013^{*}$ & $23.852^{* * *}$ \\
\hline $\begin{array}{l}\text { 2.Basamak } \\
\begin{array}{l}\text { İse Bağlllık x Kurumla } \\
\text { Ózdeşleşme Desteği }\end{array}\end{array}$ & .034 & .040 & .181 & .001 & $15.988^{* * *}$ \\
\hline
\end{tabular}

Bă̆ımlı Değişken: Kurumdan Ayrılma Niyeti

$* * *<0.001^{* *}<0.01^{*}<0.05$ 
rumla özdeşleşme ile etkileşimi incelenmiştir. Analiz sonucunda, kurumla özdeşleşmenin kurumdan ayrılma niyetini doğrudan (bağımsız değişken olarak) etkilediği görülürken, işe bağlllık ve kurumdan ayrılma niyeti ilişkisinde şartlı değişken olarak rol

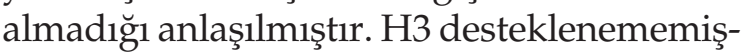
tir. Analiz sonucu Tablo 3'te gösterilmiştir.

\section{SONUÇ}

Çalışmanın amacı kurumla özdeşleşme ve işe bağlılığın kurumdan ayrılma niyetini ne oranda etkilediğini anlamaya çalışmaktır. Ayrıca çalışmamız, kurumla özdeşleşmenin işe bağlılık ve kurumdan ayrılma niyeti arasında şartlı değişken olarak rol alıp almadığını anlamayı amaçlamıştır. Verilerin analizi sonucunda, kurumla özdeşleşmenin işe bağlılığa kıyasla kurumdan ayrılma niyetini daha yüksek oranda etkilediği görülmüss, ayrıca söz konusu değişkenin işe bağlılık ve kurumdan ayrılma niyeti arasında şartlı değişken olarak rol almadığ 1 anlaşılmıştır. Kurumla özdeşleme ve işe bağlılığın kurumdan ayrılma niyeti ile ilişkisi literatürde birçok araştırmada incelenmiş olup, aralarındaki ilişkinin olumsuz olduğu ispatlanmıștır (Tüzün, 2007:129; Hafer ve Martin, 2006:14; Godwin, Guimaraes ve Igbaria, 1997:924; Mael ve Ashforth, 1995:314). Fakat, bu çalışmalar kurumla özdeşleşme ve işe bağlılı̆̆ın kurumdan ayrılma niyeti üzerindeki etkilerinin farklılaşacağını tartışmamış ve inceleme konusu haline getirmemişlerdir. Çalışmamızda işe bağlılık ve özdeşleşmenin farklı kavramlar olduğu kurumdan ayrılma niyeti üzerindeki etkilerine göre ortaya çıkmiştır. Kurumla özdeşleşmenin işe bağlılığa nazaran ayrılma niyetini daha yüksek oranda etkilemesinin sebebi özdeşleşmenin kuruma özgü bir kavram olarak gelişmesi ile ilgili yorumlanabilir. Kurumu ile özdeş kişiler o kurumun değerlerini benimseyerek kendilerini sanki o kurumun ayrılmaz bir parçası olarak hissetmektedirler (Mael ve Ashforth, 1995:312). Hâlbuki işe bağlllıkta kişi kurumu ile değil işi ile ilgili özelliklere odaklanarak bağlanmakta ve bu tür severek gerçekleştirdiği işi yaptığı bir kurumdan da ayrılmak istememektedir (Godwin, Guimaraes ve Igbaria, 1997:916; Blau and Baol, 1989:125; Blau, 1985:578). Hafer ve Martin (2006:14) yaptıkları bir çalışmada, işlerine ve örgütlerine içten bağlı (affective commitment) çalışanların kurumdan ayrılma niyetleri üzerindeki etkisini araştırmış, örgüte bağlı çalışanların ayrılma niyetlerinin işe bağlı çalışanlardan daha az olduğunu bulmuşlardır. Bu araştırma sonucunun yaptığ1mız çalışmayı destekleyici nitelikte olduğu düşünülebilir. Çünkü örgüte içten bağlılık da tıpkı özdeşleşme gibi kuruma yürekten adanmışlığ 1 içermekte olup, doğrudan kurum ile ilgili bir değişkendir. Bu yüzden işe bağlılığa oranla ayrılma niyetini daha fazla azaltmaktadır.

Kurumla özdeşleşmenin, kurumdan ayrılma niyeti ve işe bağlılık arasında şartlı bir değişken olarak rol almaması da yukarıda açıklandı̆̆ 1 gibi özdeşleşmenin güçlü doğrusal bir etkiye sahip olması ile alakalı olabilir. Blau (1985:581)'nun yaptığ 1 çalışmada benzer bir sonuç alınmış ve işe bağlılığın örgüte içten bağlılık ile etkileşime girmeden tek başına devamsızlığı azalttığı görülmüştür. Böylelikle, bu çalışma ile işe bağlılık ve özdeşleşmenin ayrı değişkenler olduğu görülerek kurumların çalışanlarına özgü uygulamalar ile işe bağlılık ve özdeşleşmelerini arttırmaları tavsiye edilmektedir. Yöneticilerin hem ișine bağlı hem de kurumu ile özdeş çalışanlar yaratması, işlerini severek yaparak kurum amaçlarına gönülden hizmet edecek çalışanlar elde etmesi sağlanmiş olacaktır.

Araştırmanın birçok olumlu katkısı bulunmaktadır. Birtakım bulguların sadece yurtdışındaki değil, Türkiye'de yapılmış çalışmalara da destek olması en önemli katkılarından biridir. Ayrıca kurumla özdeşleşme ve işe bağlılı̆̆ın ayrılma niyeti üzerindeki etkilerinin ilk olarak incelendiği bir çalışma olması açısından bundan sonra yapılacak çalışmalara ışık tutması amaçlanmaktadir. 


\section{KAYNAKÇA}

Allen N. J. \& Meyer, J.P. (1990), The Measurement and Antecedents of Affective, Continuance and Normative Commitment to the Organisation Journal of Occupational Psychology, 63:1-18.

Ashforth, B. E. \& Mael, F. (1989), Social identity theory and the organization, Academy of Management Review, 14: 20-39.

Bibby, Courtney L. (2008), Should I Stay or Should I Leave? Perceptions of Age Discrimination Organizational Justice and Employee Attitudes on Intentions to Leave, Journal of Applied Management and Entrepreneurship, 13(2): 63-86.

Blau, G. J. (1985), A Multiple Study Investigation of the Dimensionality of Job Involvement Journal of Vocational Behavior, 27: 19-36

Blau, G. J. \& Boal, K.B. (1987), Conceptualizing How Job Involvement and Organizational Commitment Affect Turnover and Absenteeism Academy of Management Review, Vol. 12(2): 288-300.

Blau, G. J., \& Boal, K. (1989), Using job involvement and organizational commitment interactively to predict turnover Journal of Management, 15: 115-127.

Bowen D. D. (1986), The Role of Identification in Mentoring Female Protegees Group \& Organization Studies, 11(1-2): 61-75.

Cameron, J. E. (2004), A three-factor model of social identity Self and Identity, 3; 239-262

Cheney, G. (1983), On the various and changing meaning of organizational membership: A field study of organizational identification Communication Monographs, 50: 342-362.
Cole, M. S. \& Bruch, H. (2006), Organizational identity strength, identification, and commitment and their relationships to turnover intention: Does organizational hierarchy matter? Journal of Organizational Behavior, 27: 585-605.

Diefendorff, M.M., Brown, D.J., Kamin, A.M. \& Lord, R.G. (2002), Examining the roles of job involvement and work centrality in predicting organizational citizenship behaviors and job performance Journal of Organizational Behavior, 23(1): 93.

Gautam, T., Van Dick, R. \& Wagner, U. (2004), Organizational identification and organizational commitment: Distinct aspects of two related concepts Asian Journal of Social Psychology, 7: 301-315.

Godwin, U.J., Guimaraes, T. \& Igbaria, M. (1997), An investigation of the antecedents of turnover for manufacturing plant managers International Journal of Operations \& Production Management, 17(9): 912.

Grandey, A. A. (1999), The Effects of Emotional Labor: Employee Attitudes, Stress and Performance Yayınlanmış doktora tezi, Colorado State University, Colorado

Griffeth, R.W., Hom, P.W. \& Gaertner, S. (2000), A Meta-Analysis of Antecedents and Correlates of Employee Turnover: Update, Moderator Tests, and Research Implications for the Next Millennium Journal of Management, 26(3): 463-488.

Hafer, J.C. \& Martin, T.N. (2006), Job Involvement or Affective Commitment: A Sensitivity Analysis Study of Apathetic Employee Mobility Institute of Behavioral and Applied Management, 2:19. 
Harris, G.E. \& Cameron, J.E. (2005), Multiple Dimensions of Organizational Identification and Commitment as Predictors of Turnover Intentions and Psychological Well-Being Canadian Journal of Behavioural Science, 37(3): 159-169.

Kanungo, R. (1982), Measurement of job and work involvement Journal of Applied Psychology, 67: 341-349.

Ketchand, A.A. \& Strawser, J.R. (2001), Multiple Dimensions of Organizational Commitment: Implications for Future Accounting Research Behavioral Research in Accounting, 13: 221.

Kitapçı, H., Çakar, N.D. \& Sezen, B. (2005), The Combined Effects of Employee Trust and Employee Identification on Intention to Quit Elektronik Sosyal Bilimler Dergisi (www.e-sosder.com), 3 (12): 33-41.

Kruml, S. M. (1999), The Heart Working: An Empirical Investigation of the Dimensions, Antecedents, and Outcomes of Emotional Labor Yayınlamış doktora tezi, Temple University, A.B.D.

Lodahl, T.M. \& Kejner, M. (1965), The Definition and Measurement of Job Involvement Journal of Applied Psychology, 49 (1): 24-33.

Loi, R., Hang-yue, N. \& Foley, S. (2006), Linking employees' justice perceptions to organizational commitment and intention to leave: The mediating role of perceived organizational support Journal of Occupational and Organizational Psychology, 79: 101.

Lyons, T. (1971), Role Conflict, Need for Clarity, Satisfaction, Tension, and Withdrawal Organizational Behavior and Human Performance, 6: 99-110.
Mael, F. A., \& Ashforth, B.E. (1992), Alumni and Their Alma Mater: A Partial Test of the Reformulated Model of Organizational Identification Journal of Organizational Behavior, 13(2): 103-123.

Mael, F.A., \& Ashforth, B.E. (1995), Loyal From Day Note: Biodata, Organizational Identification, and Turnover Among Newcomers, Personnel Psycho$\log$, 45(2): 309.

Price, J. L. (1977), The Study of Turnover Iowa State University Press.

Robbins, S.P. \& Judge, T.A. (2007), Organizational Behavior Prentice Hall, New Jersey.

Scott, C.R, Connaughton, S.L. Diaz-Saenz, H.R., Maguire, K., Ramirez, R., Richardson, B., Shaw, S.P. \& Morgan, D. (1999), The impacts of communication and multiple identifications on intent to leave Management Communication Quarterly, 12(3): 400.

Shore, L. M. \& Martin, H. J. (1989), Job Satisfaction and Organizational Commitment in Relation to Work Performance and Turnover Intentions Human Relations, 42(7): 625-638.

Shore, L. M., Newton, L. A., \& Thornton, G. C. III. (1990), Job and organizational attitudes in relation to employee behavioral intentions Journal of Organizational Behavior, 11: 57-67.

Somers, M.J. (1995), Organizational Commitment, Turnover and Absenteeism: An Examination of Direct and Indirect Effects Journal of Organizational Behavior, 16: 49-58.

Tett, R. P., \& Meyer, J. P. (1993), Job Satisfaction, Organizational Commitment, Turnover Intention and Turnover: Path Analyses Based on Meta Analytical Findings Personnel Psychology, 46(2): 259-290. 
Tüzün, Kalemci İ. (2007), Antecedents of Turnover Intention toward a Service Provider The Business Review, Cambridge, 8(2): 128.

Van Knipperberg, D. \& Van Schie, E.C.M. (2000), Foci and correlates of organizational identification Journal of Occupational and Organizational Psychology, 73-137.

Wegge, J., Van Dick, R., Fisher, G.K., Wecking, C. \& Moltzen, K. (2006), Work motivation, organizational identification, and well-being in call centre work Work \& Stress, 20(1): 60-83.

Weisberg, J. \& Kirschenbaum, A., (1991), Employee Turnover Intentions: Implications from a National Sample The International Journal of Human Resource Management, 2(3): 359-375. 
